\title{
Implementasi Media Facebook dalam Meningkatkan Perilaku Moral pada Anggota Lembaga BPD (Badan Permusyawaratan Desa) Kabupaten Nganjuk
}

\author{
${ }^{1}$ Sony Eko Adisaputro, ${ }^{2}$ Mohammad Sholeh Kamid \\ ${ }^{1}$ IAI Pangeran Diponegoro Nganjuk, ${ }^{2}$ IAI Pangeran Diponegoro Nganjuk \\ ${ }^{1}$ sonyeko@iaipd-nganjuk.ac.id, ${ }^{2}$ sholehkamid@iaipd-nganjuk.ac.id
}

\begin{abstract}
ABSTRAK
Media online merupakan media yang akan memberikan kemudahan masyarakat untuk melakukan kebutuhan akan informasi. Media online yang kini perkembangannya sangat pesat yaitu media sosial Facebook, dibandingan dengan media sosial lainnya. Dengan adanya media online facebook dapat terwujudnya berbagai bentuk perilaku seseorang baik di dunia maya maupun nyata. Manajemen yang baik dapat meningkatkan perilaku seseorang. Akan tetapi dalam penggunaan media online facebook, manajemen yang diterapkan oleh anggota BPD rata - rata masih belum diketahui.
\end{abstract}

Berdasarkan kontek penelitian tersebut, peneliti merumuskan focus penelitan yang terdiri dari : (1) Bagaimana perencanaan media online facebook dalam meningkatkan perilaku moral pada anggota lembaga BPD, (2) Bagaimana pelaksanaan media online facebook dalam meningkatkan perilaku moral pada anggota lembaga, (3) Bagaimana pengawasan penggunaan media online facebook dalam meningkatkan perilaku moral pada anggota lembaga BPD.

Penelitian ini merupakan penelitian kualitatif deskriptif analitik dengan rancangan penelitian berupa studi multi situs sebagai rancangan penelitian ini agar peneliti dapat mengamati secara cermat mengenai suatu program, peristiwa, fenomena, aktivitas, proses serta kegiatan mengenai objek yang akan diteliti. pengumpulan data dilakukan dengan teknik pengumpulan data wawancara mendalam (In depth interview) dokumentasi, observasi. Untuk menganalisis data, penelitian ini menggunakan analisis data induktif dengan pendekatan induktif membuka kemungkinan untuk melakukan penemuan atau discovery, serta penelitian ini menggunakan teknik keabsahan data berupa trianggulasi dan member check, untuk trianggulasi menggunakan trianggulasi sumber dan trianggulasi metode.

Berdasarkan hasil penelitian ini dapat disimpulkan bahwa BPD di desa merupakan : (1) perencanaan media facebook berusaha mempertahankan pesan positif dan mempertimbangkan berbagai postingan agar tidak melibatkan permasalahan yang panjang dan pemilihan-pemilihan informasi postingan didasarkan pada tujuan dan manfaat pribadi maupun untuk tim BPD, selain itu sebagai sarana aspirasi masyarakat khususnya. (2) pelaksanaan media online facebook didasarkan pada perencanaan dan pengorganisasian, berbagi kegiatan dan pesan pemerintahan, keagamaan (dakwah) dan informasi-informasi penting lainnya untuk inspirasi publik maupun citra diri seta eksistensi diri dan lembaga. (3) pengawasan media online facebook pelaksanaan dikoreksi sedemikian rupa, secara bertahap konsisten terhadap postingan positif dan klarifikasi mengenai bentuk 
ketidak nyamanan user lain dan teguran pimpinan untuk tim yang menyimpang di dalam penggunaan media online facebook.

\section{Kata Kunci: Media Fecebook, Perilaku Moral}

\section{PENDAHULUAN}

Media merupakan alat untuk membantu mempermudah manusia beraktifitas sehari-hari. Dalam hal ini perkembangan media mulai menjawab seluruh kebutuhan masyarakat secara keseluruhan khususnya media online. Media online merupakan layanan media yang dapat diakses oleh masyarakat atau kelompok masyarakat melalui internet, selain itu media online merupakan media yang akan memberikan kemudahan masyarakat untuk melakukan kebutuhan akan informasi.

Persentase penggunaan internet di Indonesia memicu banyaknya pengguna media sosial yang saat ini terdapat banyak media sosial yang ditawartkan oleh perusahan aplikasi yang dapat dimanfaatkan oleh masyarakat, organisasi dan perusahaan. Dalam hal ini media sosial yang kini perkembangannya sangat pesat yaitu media sosial Facebook dibandingan dengan media sosial lainnya. Media sosial facebook berdiri atau dirilis pada tahun 2004 bulan Februari yang didirikan oleh Mark Zuckerberg, seorang lulusan Harvard dan alumni murid Ardsley High School. Facebook merupakan media sosial yang mudah diakses oleh siapa pun dengan memberikan kenyamanan baik tampilan maupun kemudahan dalam penggunaanya, selain itu facebook dapat di manfaatkan oleh setiap golongan baik golongan masyarakat bawah, menengah dan atas bahkan sampai kepada para pelajar saat ini menggunakan facebook. Oleh karena itu facebook dapat dikatakan media sosial yang dapat mempengaruhi pola pikir dan prilaku masyarakat dalam berkomunikasi baik antar pribadi maupun kelompok.

Dengan adanya media online facebook dapat terwujudnya berbagai bentuk perilaku seseorang baik di dunia maya maupun nyata. Dalam hal ini, kemampuan facebook untuk mempengaruhi penggunanya beraneka ragam baik berdampak positif maupun negatif. Sehingga hal ini berdampak pula pada prilaku moral seseorang. Perilaku moral merupakan bentuk proses berfikir seseorang dalam bertindak sesuai pertimbangan tertentu yakni ke hal negatif atau positif.

Sehingga hal ini perlu adanya sebuah pembatasan dalam sesorang berperilaku baik di dunia nyata maupun maya. Penerapan manajemen yang baik tentu saja dapat meningkatkan perilaku moral seseorang. Penelitian ini fokus pada anggota lembaga BPD (Badan Permusyawaratan Desa).

Badan Permusyawartan Desa (BPD) merupakan lembaga perwujudan demokrasi dalam penyelenggaraan pemerintah desa atau dapat disebut sebagi badan parlemen desa yang mempunyai tugas dan wewenang untuk menggali, menampung mengelola dan menyalurkan aspirasi masyarakat. Oleh karena itu, untuk membantu 
mewujudkan tujuan BPD tersebut bahwa perkembangan media sosial facebook dapat membantunya menampung aspirasi masyarakat desa Se Kab. Nganjuk.

Manajemen yang baik dapat meningkatkan perilaku seseorang. Peningkatan perilaku ini mengarah ke moral yang positif sebagai salah satunya dalam penggunaan media facebook. Sehingga peran perangkat desa seperti bagian lembaga BPD desa mampu menggunakan dengan bijak media yang tidak mengenal waktu, khalayak maupun asumsi-asumsi lainnya.

Akan tetapi peneliti belum memahami secara pasti manajemen yang diterapkan oleh anggota BPD Desa Se Kab. Nganjuk dalam penggunaan media online facebook. Untuk memahami tersebut peneliti meyakini bahwa harus terlebih dahulu mengungkap lebih mendalam kasus-kasus tersebut dalam berbagai fungsi manajemen dan belajar berperilaku moral sehingga dapat menghantarkan individu pada tahap peningkatan perilaku moral pada anggota BPD Desa Se Kab. Nganjuk

\section{METODE PENELITIAN}

Metode penelitian yang digunakan dalam penelitian ini adalah metode penelitian kualitatif dengan jenis deskriptif. Menurut Moleong penelitian kualitatif adalah penelitian yang bermaksud untuk memahami fenomena tentang apa yang dialami oleh informan penelitian misalnya perilaku, persepsi, minat, motivasi, tindakan, dan lain sebagainya. ${ }^{1}$ Oleh karena itu penelitian ini dapat diartikan sebagai metode yang memberikan hasil dari data penelitan dilapangan yang berkenaan dengan interprestasi terhadap data yang dihasilkan sebagai bentuk kebenaran dari berbagai asumsi yang terjadi sebelum dilakukan penelitian.

Jenis penelitian yang digunakan pada penelitian ini adalah jenis penelitian kualitatif deskriptif. Menurut Moleong penelitian deskriptif adalah peneliti yang mengeksplorasi serta mengumpulkan data berupa kata-kata, gambar, dan bukan angka-angka atau dapat diartikan bahwa peneltian deskriptif adalah suatu bentuk penelitian yang ditujukan untuk mendeskripsikan atau menggambarkan fenomenafenomena yang ada, baik fenomena alamiah maupun rekayasa manusia ${ }^{2}$. Sehingga dari hasil penelitian ini akan berupa kata-kata yang tertulis atau lisan dari perilaku yang diamati. Adapun tujuan penelitian deskripti adalah untuk membuat pencandraan secara sistematis, faktual dan akurat mengenai fakta dan sifat populasi atau daerah tertentu. Penelitian ini digunakan untuk mengetahui manajemen media online facebook dalam meningkatkan prilaku moral pada anggota lembaga Badan Permusyawaratan Desa (BPD) Jatigreges Kecamatan Pace Kabupaten Nganjuk.

Penelitian tentang manajemen Media Online Facebook Dalam Meningkatkan Moral Pada Anggota Lembaga Badan Permusyawaratan Desa (BPD)

\footnotetext{
${ }^{1}$ Moleong. "Penelitian Kualitatif". 2014. PT. Remaja Rosdakarya Bandung. Hal. 6

${ }^{2}$ Ibid. hal. 11.
} 
Desa Jatigreges Kecamatan Pace Kabupaten Nganjuk. Oleh sebab itu untuk dapat menganalisis dan mengetahui manajeman dalam penelitian ini maka peneliti menggunakan pendekatan metodologi studi kasus. Menurut Krisyantoro Studi kasus dapat diartikan sebagai metode riset yang menggunakan sumber data yang dapat digunakan untuk meneliti, menguraikan dan menjelasakan secara komprehensif sebagai aspek individu. Penggunaan studi kasus ini merupakan pertimbangan dari beberapa hal unik untuk menggali informasi dari organisasi atau lembaga ${ }^{3}$.

Alasan yang mendasar peneliti menggunanakan metode studi kasus, karena peneliti dapat terfokus pada satu fenomena, yaitu begaimana manajemen media online facebook dalam meningkatkan perilaku moral pada anggota lembaga BPD baik berupa peningkatan kualitas anggota, komunikasi antar anggota dan emosional anggota satu dengan anggota yang lain.

Peneliti harus hadir dalam tempat penelitian agar dapat mengamati orang yang akan digunakan sebagai sumber data penelitian, tetapi tidak ikut terlibat dalam kegiatan tersebut. Kedudukan peneliti dalam penelitian kualitatif cukup rumit, peneliti merupakan perencana, pelaksana pengumpulan data, analisis, penfsiran data, dan hasilnya akan menjadi laporan hasil penelitiannya. Selain itu, kehadiran peneliti diketahui statusnya oleh Subjek atau informan.

\section{HASIL DAN PEMBAHASAN}

Manajemen ini dapat dilihat dari bagaimana anggota BPD merencanakan dan mempertimbangkan dalam penggunaan media online facebook. Perencanaan ini tidak hanya menjadi perencanaan dalam bidang pekerjaan maupun kegiatan lainnya. Namun, sebagai anggota BPD yang kerap di hubungkan pada tokoh yang berpengaruh dalam masyarakat ada baiknya mempertimbangkan pula pada penggunaan media online yakni facebook. Hal ini dapat dipertimbangkan melalui pesan yang akan disampaikan, khalayak atau teman dan efek yang akan terjadi.

Menurut hasil observasi yang dilakukan oleh peneliiti bersama Didik Suharmanto di desa Jatigreges tanggal 21 April 2018. Saat itu merupakan hari Kartini dan lembaga PKK mengadakan acara Kartinian, akan tetapi Didik mengikuti kegitan tersebut meskipun bukan acara lembaga BPD. Didik membantu persiapan dan kehadirannya disambut dengan baik oleh teman-teman yang lainnya. kegiatan tersebut di abadikan oleh Didik lewat poselnya dan selanjutnya di posting di media online facebooknya. Begitu juga dengan informan Sumarni yang juga membantu dan mengikuti kegiatan tersebut dengan tanggung jawab penuh.

Deskripsi ini seperti yang disampaikan George R. Terry dalam fungsi perencanaan, hal ini sesuai yang diampikan George $\mathrm{R}$ Terry bahwa pemilih fakta dan penghubungan fakta fakta serta pembuatan dan penggunaan perkiraan-perkiraan

\footnotetext{
${ }^{3}$ Krisyantoro, Rahmat. "Teknik Praktik Riset Komunikasi”. 2008. Jakarta: Kencana Prenada Media. Hal 56-57
} 
atau asumsi-asumsi untuk masa yang akan datang dengan jalan menggambarkan dan merumuskan kegiatan-kegiatan yang diperlukan untuk mencapai hasil yang diinginkan. Dalam hal ini anggota BPD untuk meningkatkan perilaku moral perlu adannya perencanaan dan pemikiran-pemikiran sesuai fakta yang pada akhirnya dapat terealisasikan baik di dalam kehidupan nyata maupun maya. Sehingga perumusan kegitan tersebut itulah yang dapat dimanfaatkan untuk berbagi informasi ke khalayak banyak di media facebook. pencapainnya akan terlihat pada respon positif pengguna facebook lainnya khususnya masyarakat desa Jatigreges, tidak hanya sebagai bentuk kemampuan peningkatan moral akan tetapi dapat membentuk citra baik lembaga khususnya pribadi informan.

Hal ini didukung oleh hasil wawancara dengan wakil BPD desa Jatigreges yaitu Dian Teguh Sasmito pada 23 April 2018.

"Kalau di facebook saya mempersiapkannya tentu kita fikirkan dulu apa yang di posting kira-kira bermanfaat atau tidak..nah seperti itu biasanya mbak."

Berdasarkan hasil wawancara tersebut informan mencoba memberikan berbagai hal yang positif mengenai pesan maupun informasi-informasi lain kepada khalayak. Persiapan ini didasarkan pada pertimbangan-pertimbangan tertentu, seperti pesan, pertemanan dan efek yang akan timbul apabila memposting maupun berkomentar yang tidak baik. Sehingga hal ini tidak merugikan diri sendiri dan khalayak banyak.

Berdasarkan postingan yang disampaikan lewat status di facebook tersebut, informan mencoba menjelaskan kepada publik bahwa apapun informasi yang akan disampaikan ke publik sebaiknya dipahami dan telusuri kebenarannya sebelum di posting di publik. Informasi yang langsung di share tanpa adanya proses pemahaman dan perencanaan yang baik akan menimbulkan informasi yang hoax atau salah yang dapat merugikan diri sendiri mupun khalayak banyak. Sehingga penilti menyimpulkan informan sebelum menshare segala bentuk informasi selalu memperhatikan setiap kata dan pesan tersebut dapat bermanfaat dan menjadi inspirasi publik. Sehingga perencanaan tidak hanya mengenai sebuah pekerjaan di instansi atau perusahaan akan tetapi perencanaan untuk media online perlu adanya pertimbangan dan pemikiran yang positif.

Perencanaan dan segala bentuk tujuan selalu menjadi tugas yang akan dilaksanakan. Dalam setiap organisasi seperti lembaga BPD, pimpinan dan tim perlu adanya kerja sama yang baik untuk melaksanakan tugas dan tujuan mereka. Anggota BPD desa Jatigreges dalam pelaksanaan tugas sangat dipengaruhi oleh media. Hal ini kaitannya dengan koordinasi pembagian tugas. Bukian hal baru lagi, bahwa media sosial sangat berpengaruh dalam segala lini pekerjaan saat ini. Sehingga anggota BPD desa Jatigreges sangat bergantung dengan media ini. Bukan

${ }^{4}$ Wawancara dengan Bapak Dian Teguh Sasmito, pada 23 April 2018 pukul 21.31 WIB 
hal baru juga, bahwa facebook merupakan media yang sangat berpengaruh besar terhadap eksistensi seseorang, perusahaan maupun bangsa.

Hal ini didukung oleh hasil wawancara ketua BPD desa Jatigreges informan Didik Suharmanto pada 23 April 2018

"Untuk dorongan yang jelas saya selalu memberikan masukanmasukan agar teman-teman sesama anggota BPD dan juga masyarakat secara umum yang ada khususnya di desa jatigreges yang jelas kami harapkan ketika ada informasi-informasi terkait mungkin kegiatan-kegiatan yang ada di desa saya menghimbau kepada mereka agar bisa di sampaikan atau di publiikasikan dan agar nanti bisa menjadi bahan masukan bagi kami di BPD dan juga untuk mendapatkan pertimbangan-pertimbangan ataupun masukan kepada teman-teman pengguna facebook yang lain.",

Bedasarkan hasil wawancara tersebut bahwa tim anggota BPD mengelola facebook dengan hal-hal positif, yang dapat memberikan pengaruh positif terhadap publik. Informasi yang posting sedemikian rupa sudah direncanakan oleh masingmasing anggota BPD. Tidak hanya mempertimbangan mengenai manfaatnya akan tetapi anggota BPD juga mempertimbangkan mengenai dampak yang akan terjadi sebagai akibat dari postingan. Anggota BPD merupakan cerminan rakyat banyak, sehingga mereka lebih berhati-hati dalam menyampaikan pesan dan merespon komentar khalayak.

Berdasarkan pesan yang diposting salah satu anggota BPD desa Jatigreges yakni Dian Teguh Sasmito, dalam setiap postingan yang di share selalu mengenai hal-hal positif, salah satunya membagikan informasi mengenai keagamaan dan berbagai informasi positif lainnya. Hal ini dapat meningkatkan moral positif informan baik di kehidupan nyata maupun maya

Berdasarkan komentar sindiran yang disampaikan oleh netizen di kolom komentar didik suharmanto. Peneliti dapat menyimpulkan bahwa konflik apapun di dalam pemerintahan desa dan berlanjut ke dalam media facebook, informan menanggapi dengan bijak. Tidak hanya secara langsung akan tetapi pembicaraan bijak dapat mempertahankan hubungan yang baik kepada orang yang tidak menyukai kebijakan dan keputusan yang sudah terjadi.

Perilaku moral dibentuk dan dapat meningkat dengan adanya pengawasan. Pengawasan ini berlaku untuk siapa saja termasuk anggota BPD desa Jatigreges. Apalagi di dalam media online facebook apapun yang tidak dikontrol akan berdampak pada hal-hal negatif. Sehingga dampak ini tidak hanya terjadi dalam media online facebook tetapi juga pada kehidupan nyata. Akibat dari pada itu kerugian dan citra diri maupun lembaga dapat tercemar.

Hal ini didukung oleh hasil wawancara ketua BPD desa Jatigreges informan Didik Suharmanto pada 23 April 2018.

\footnotetext{
${ }^{5}$ Wawancara dengan Bapak Didik Suharmanto, pada 23 April 2018 pukul 20.02 WIB
} 
"Kalau untuk pengawasan pada teman-teman yang lain dalam penggunaan media facebook, sebetulnya menurut saya sendiri kurang. Karena apa, saya sendiri juga tidak full time untuk update selalu dalam penggunaan facebook ya. Paling tidak entah itu beberapa waktu entah itu beberapa hari sekali paling tidak saya mencoba melihat hal-hal apa yang sekiranya teman-teman posting ataupun teman-teman share ke dalam media facebook dan mungkin ketika hal-hal tersebut ada sekiranya kurang pas ataupun kurang layaknya tentu kami akan melakukan klarifikasi ataupun masukanmasukan kepada mereka secara personal"

Berdasarkan hasil wawancara tersebut, pengawasan terhadap diri masingmasing anggota BPD cukup baik Karena pengawasan yang baik tanpa sadar apapun yang disampaikan ke media online adalah bentuk bentengan diri untuk mempertahankan perilaku yang bermoral. Pertemanan di dalam media online facebook sangat mempengaruhi postingan seseorang. Hal ini ditemukan peneliti di dalam akun Sumarni bahwa informan sangat jarang sekali memposting gambar atau status akan tetapi teman-teman facebook nya membagikan kegiatan yang sedikit vulgar yang seharusnya tidak dibagikan ke publik. Dalam sudut pandang orang lain, hal itu tetap memberikan pengaruh negatif meskipun dari sudut pandang yang positif diacungi jempol misalkan dalam hal kebersamaan.

Hal ini didukung pula oleh hasil wawancara kepada informan Dian Teguh Sasmito pada 23 April 2018.

"Kalau dipekerjaan yang lain mungkin saya bisa mengontrol karena disitu sebagai kepala program, jadi kalau di BPD tentunya tidak perlu ada pengontrolan yang lebih karena anggota yang tidak cukup banyak sehingga tidak begitu penting atau tidak perlu ada pengontrrolan yang lebih. Karena kan hanya sekedar informasi penting kemudian pesan singkat atau undangan hanya seperti itu. Kalau pribadi tentu kontrolnya lebih, khususnya untuk postingan tentu kita share lebih condong kepada teman bukan kepada public kalau kepada public nanti semua yang ada di media facebook membacanya kalau itu sampai dengan pemikiran semua orang mungkinoke-oke saja. Tapi kalau tidak sesuai itu akan jadi masalah juga." 7

Berdasarkan hasil wawanacara tersebut, bentuk control diri terhadap media online memang harus ketat, karena facebook merupakan media public, di penjuru

\footnotetext{
${ }^{6}$ Wawancara dengan Bapak Didik Suharmanto, pada 23 April 2018 pukul 20:44 WIB

${ }^{7}$ Wawancara dengan Bapak Dian Teguh Sasmito, pada 23 April 2018 pukul 21:41 WIB
} 
dunia dapat melihat dan membaca postingan yang di share. Jika tidak berhati-hati dapat menuai permasalah dan bisa mempengaruhi kehidupan nyata.

\section{SIMPULAN DAN SARAN}

Dengan memperhatikan uraian penelitian, hasil temuan penelitian, dan pembahasan mengenai manajemen media online facebook dalam meningkatkan perilaku moral pada anggota lembaga Badan Permusyawaratan Desa (BPD) desa Jatigreges kecamatan Pace kabupaten Nganjuk, maka penelitian ini dapat penulis simpulkan.

1. Perencanaan postingan positif dan bermanfaat. citra diri sebagai pertahanan pribadi untuk mengelola identitas, pemilihan pesan dan seleksi pertemanan dan mempertimbangkan efek yang akan terjadi. Persiapan diutamakan postingan yang berkualitas agar menjadi sarana terbaik aspirasi dan inspirasi masyarakat.

2. Pelaksanaan dinilai positif karena menghasilkan berbagai informasi yang positif dan dapat dimanfaat oleh masyarakat secara luas. Sehingga pencapaian ini terbilang sukses untuk mempertahankan perilaku moral baik dalam dunia kerja maupun dunia maya anggota.

3. Pengawasan kurang baik sehingga masih ada hal-hal yang sedikit menyimpang dalam etika penggunaan media online facebook. Evaluasi dilakukan lewat chat personal oleh pimpinan anggota BPD, memperingatkan untuk citra pribadi dan lembaga BPD khususnya.

\section{DAFTAR PUSTAKA}

Abidin, Yusuf Z, Manajemen Komunikasi: Filosofi, Konsep, dan Aplikasi, Bandung: Pustaka Setia, 2015.

Arif, N.F., Zulkarnain, Iskandar, Dasar-dasar Manajemen dalam Teknologi Informasi, Jurnal SAINTIKOM Vol. 5, No. 2 Agustus 2008, 237.

Kapang, Fredy Y2009. Planet facebook: 6 jurus ampuh menguasai facebook. Yogyakarta: Cemerlang Publishin.

Krisyantoro, Rahmat. “Teknik Praktik Riset Komunikasi”. 2008. Jakarta: Kencana Prenada Media.

Moleong. "Penelitian Kualitatif”. 2014. PT. Remaja Rosdakarya Bandung.

Sugiyono. "Metode Penelitian Kuantitatif, Kualitatif dan R\&D”. 2014. AlFabeta Bandung.

Yacoeb, M., Konsep Manajemen dalam Perspektif Alqur'an: Suatu Analisis dalam Bidang Administrasi Pendidikan. Jurnal Ilmiah DIDAKTIKA Agustus 2013 VOL. XIV NO. 1, 75.

Yeni Rizal. "Perilaku Moral Remaja Dalam Persepektif Budaya”. Vol. 1, No. 1, Maret 2017. 